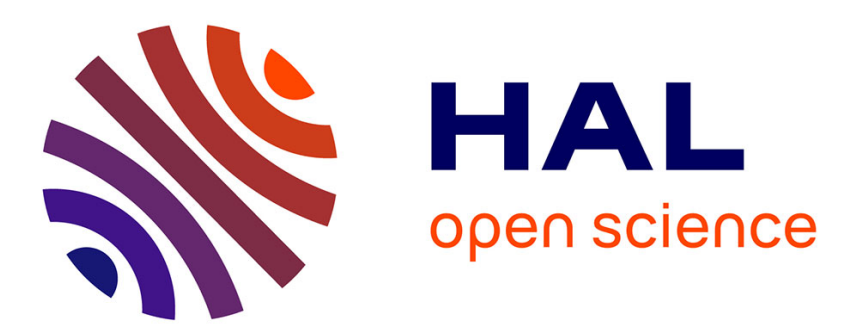

\title{
A COMPUTER ANALYSIS OF INTERACTION OF UV LASER PULSES WITH THIN METALLIC LAYERS
}

L. Pokora, J. Zmywaczyk

\section{- To cite this version:}

L. Pokora, J. Zmywaczyk. A COMPUTER ANALYSIS OF INTERACTION OF UV LASER PULSES WITH THIN METALLIC LAYERS. Journal de Physique IV Proceedings, 1991, 01 (C7), pp.C7-189C7-189. 10.1051/jp4:1991751 . jpa-00250993

\section{HAL Id: jpa-00250993 https://hal.science/jpa-00250993}

Submitted on 1 Jan 1991

HAL is a multi-disciplinary open access archive for the deposit and dissemination of scientific research documents, whether they are published or not. The documents may come from teaching and research institutions in France or abroad, or from public or private research centers.
L'archive ouverte pluridisciplinaire HAL, est destinée au dépôt et à la diffusion de documents scientifiques de niveau recherche, publiés ou non, émanant des établissements d'enseignement et de recherche français ou étrangers, des laboratoires publics ou privés. 


\section{A COMPUTER ANAIYSIS OF INTERACTION OF UV LASER PULSES WITH THIN METALLIC LAYERS}

L. POKORA and J. ZMYWACZYK

Institute of Quantum Electronics, Kaliskiego St. 6, PL-01-489 Warsaw, Poland

\section{ABSTRACT}

The results of computer analysis of interaction of UV $(\lambda=308,337 \mathrm{~nm}$ ) laser pulses with thin metallic layers ( $\mathrm{Ag}, \mathrm{Cr}, \mathrm{Cu}$ ) laid on a ceramic base were presented in this paper.

Two-dimensional model of heat transfer

$$
P_{i}\left(T_{i}\right) C_{P_{i}}\left(T_{i}\right) \frac{\partial T_{i}}{\partial \tau}=\operatorname{div}\left(k_{i}\left(T_{i}\right) \operatorname{grad} T_{i}\right) ; i=1,2
$$

with Stefan's condition at the phase boundary

$$
\left.k(T)(\bar{n} \cdot \operatorname{grad} T)\right|_{L}-\left.k(T)(\bar{n} \cdot \operatorname{grad} T)\right|_{S}=\rho L \bar{v} \cdot \bar{n}
$$

where $p(T), c_{p}(T), k(T)$ denote the temperature-dependent density, heat capacity and thermal conductivity of " $i$ "-layer, L-heat of fusion, $\bar{v}$ - phase change surfice velocity, $\bar{n}$ - unit vector perpendicular to the surfice of phase change, 1,5 - liquid or solid state respectively has been taken into cosideration. Both the time and space distribution of laser beam as well as heat losses by conduction and radiation have been considered, too.

The melt's shape as a function of laser parameters computed numerically, next had been compared with the experimental results. by using of an early elaborated lasers $[1,2]$

1. L. Iwanejko, M. Stefanski, Z. Ujda, L. Pokora Froc, SPIE vol.859, P. 249, 1987

2. J. Chłodzinski, J. Kutyła, J. Makuchowski, L. Fokora Proc. SPIE vol.859, p.54, 1987 